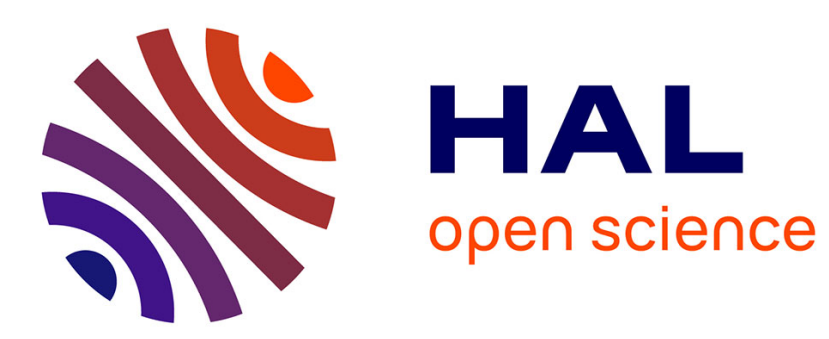

\title{
Experimental modelling of urban flooding: A review
}

Emmanuel Mignot, Xuefang Li, Benjamin J. Dewals

\section{To cite this version:}

Emmanuel Mignot, Xuefang Li, Benjamin J. Dewals. Experimental modelling of urban flooding: A review. Journal of Hydrology, 2019, 568, pp.334-342. 10.1016/j.jhydrol.2018.11.001 . hal-02381264

\section{HAL Id: hal-02381264 \\ https://hal.science/hal-02381264}

Submitted on 29 Nov 2019

HAL is a multi-disciplinary open access archive for the deposit and dissemination of scientific research documents, whether they are published or not. The documents may come from teaching and research institutions in France or abroad, or from public or private research centers.
L'archive ouverte pluridisciplinaire $\mathbf{H A L}$, est destinée au dépôt et à la diffusion de documents scientifiques de niveau recherche, publiés ou non, émanant des établissements d'enseignement et de recherche français ou étrangers, des laboratoires publics ou privés. 


\section{Experimental modelling of urban flooding: a review}

Emmanuel Mignot ${ }^{\mathrm{a}^{*}}$, Xuefang $\mathrm{Li}^{\mathrm{b}}$, Benjamin Dewals ${ }^{\mathrm{b}}$

${ }^{\text {a }}$ University of Lyon, INSA Lyon, CNRS, LMFA UMR5509, F-69621 Villeurbanne, France

${ }^{\mathrm{b}}$ Hydraulics in Environmental and Civil Engineering (HECE), University of Liège (Uliège), Belgium

* Corresponding author: Emmanuel.mignot@insa-lyon.fr

\section{Abstract}

We review the 45 available studies of urban flooding based on laboratory experiments. We distinguish between the studies focusing on the flow in (i) a single street intersection, (ii) surface-sewer exchanges, (iii) an array of obstacles and (iv) quasi-realistic urban districts. We discuss the main flow processes which are covered in the various studies and detail which flow variables were recorded. This enables identifying flow processes for which comprehensive experimental datasets are available from those which require additional experimental research. We also highlight the typical ranges of scale factors used, which depend mainly on the extent of the studied area (from very local up to the district level). This review aims at helping computational modellers to pinpoint the most suitable dataset for validating their numerical approaches and laboratory modellers to identify gaps in current experimental knowledge of urban flooding.

Keywords: urban flood; experimental models; databases; flow processes; model set-ups.

\section{Introduction}

Among all natural disasters, floods are the most frequent and they affect the highest number of people globally (UNISDR, 2015). Flood risk is particularly severe in urban areas (Chen et al., 2015). Improving urban flood risk management has become a high priority at virtually all levels of governance (Fang, 2016). The proper design and evaluation of measures to enhance urban floodresilience should be based on the analysis of a range of scenarios, in which various hydrometeorological conditions and management options are tested. This requires the accurate modelling of inundation extents, water depths, discharge partition and flow velocity in urbanized flood prone areas, since these parameters are critical inputs for flood impact modelling (Kreibich et al., 2014). 
For relatively rural areas, flood modelling and inundation mapping have become common practice (Falconer et al., 2017; Teng et al., 2017). Based on the 1D or 2D shallow-water equations (SWE), the accuracy of these computations depends mainly on the quality of hydrological and topographic input data (Dottori et al., 2013). In contrast, floods in urban areas exhibit more diverse and complex flow processes, as the water follows multiple flow paths such as crossroads, sewers, courtyards, parks, flow around or within buildings and pieces of urban furniture (Paquier et al., 2015; Falconer et al., 2017). Numerical models used for urban flood simulations need to account for these specific features of the urban environment. For about two decades, the quality and complexity of urban flood simulations have steadily increased. Starting from standard 1D or 2D models (Mark et al., 2004; Mignot et al., 2006a), more sophisticated numerical approaches have become gradually available:

- additional processes were included in the models, such as the rain falling directly on the street network (Pons et al., 2005; Paquier and Bazin, 2014), short waves or tsunami long waves invading a city (Park et al., 2013), human evacuation during a flood (Bernardini et al., 2017), among others;

- high resolution digital elevation models (DEM), such as laser altimetry with a resolution as fine as $0.5 \mathrm{~m}$ in some urban areas (Van Ootegem et al., 2016), have enabled super precise descriptions of the urban domains (Ozdemir et al., 2013);

- isotropic and anisotropic porosity-based models (e.g., Bruwier et al. (2017)), coupled 1D (in streets) and 2D (in crossroads) models (Ghostine et al., 2015), as well as improved computational techniques such as cloud computing (Glenis et al., 2013) or model implementation on graphical processing unit (Apel et al., 2016; Smith et al., 2015), have been developed to enable efficient coverage of large spatial areas;

- although still in its infancy, modelling the interactions between surface flow and the sewer system has been tested, based on a 1D description of the underground system and $0 \mathrm{D}, 1 \mathrm{D}$ or 2D approaches for surface flow, each with scientific challenges (Leandro et al., 2009; Seyoum et al., 2012; Bazin et al., 2014). 
Nonetheless, further numerical developments are needed to incorporate more details (urban furniture, street profiles, façade misalignments, parked cars) as well as additional processes generally overlooked so far (water entering the buildings, more realistic interactions river/surface/sewers, transport of cars, pollutants, computing rescue operations ...). Since 3D computations (Ghostine et al., 2009; Gems et al., 2016; Rodi, 2017) will not be a viable option for operational flood analysis and mapping in the coming years, many processes will not be captured explicitly by operational flood models. They will have to be reproduced through appropriate analytical-empirical parametrizations. The development and validation of these parametrization requires high quality and reliable reference data.

Field data, such as watermarks and aerial imagery, remain generally scarce, uncertain and insufficient to reflect the whole complexity of inundation flows in urbanized flood-prone areas, particularly under more extreme future conditions (Neal et al., 2009). Additional information on the velocity fields and discharge partitions are necessary to understand the multi-directional flow pathways induced by the built-up network of streets, buildings and underground systems (e.g., drainage network). There is also a lack of observations of pluvial urban floods, mainly due to the short duration and local nature of intense rainfall events. To address this lack of validation data from the field, laboratory models are an appealing alternative, since they provide accurate measurements of flow characteristics under controlled conditions.

Therefore, this paper aims at reviewing the existing datasets of urban flood laboratory experiments. This review may benefit to both numerical modellers willing to test and validate innovative computational approaches, and experimentalists looking for comparison datasets or willing to close knowledge gaps. The paper presents also an inventory of the flow processes for which experimental research was undertaken or still to be handled. Field data are excluded on purpose, as they are generally sparser and more uncertain.

The paper is organized in three parts. The existing experimental datasets dedicated to the analysis of urban flood processes are reviewed in Sect. 2. In Sect. 3, the coverage of the main urban flood process by dedicated laboratory experiments is evaluated; enabling us to point out the flow processes for 
which no or limited experimental data are currently available. Finally, Sect. 4 links the main findings to the corresponding numerical approaches, highlighting those which lack validation data. Hints for future experimental research are proposed.

\section{State of the art of available urban flood datasets}

Table 1 lists the available experimental datasets related to urban flooding. Most experiments were performed in the last 15 years, suggesting a growing worldwide interest for urban flood laboratory data, as the corresponding numerical models also improved considerably. The experimental studies focused on four main flow types: (i) flow in street intersections, (ii) vertical exchanges between the sewer system and the streets, (iii) flow within regular grids of emerging rectangular obstacles representing idealized buildings or building blocks and (iv) flow within more realistic urban districts. Table 1 is organized in four blocks (I to IV), each of them corresponding to one flow type.

As shown in the first column of Table 1, the experiments considered five different origins of the water, i.e. the cause of flooding. First, upstream runoff (UR) corresponds to experiments in which the water is supplied from an upstream boundary, mainly via a reservoir with a controlled discharge. It usually refers to flood events for which the overflow or rain takes place upstream of the urban area and water enters the urban domain as surface flow. Second, river overflow (RO) corresponds to configurations where the overflow takes place within the urban area and thus the river and the overtopping of the banks are explicitly included in the experiments. In such a case, the upstream boundary condition is a controlled discharge within the river. Sewer overflow (SO) is similar to river overflow except that in this case the water invading the surface comes from an exceeded capacity of the sewer within the urban domain; the upstream boundary condition is then a controlled discharge in the sewer inlet. The fourth origin of water is the rainfall over the studied domain (RA), which is the case of fully urban watersheds (Pons et al., 2005; Paquier and Bazin, 2014). Then the upstream boundary condition is a complex spatial (and temporal) distribution of water jets from a wellcontrolled rainfall simulator. Finally, the tsunami (TS) type is a long wave imposed off-shore that propagates over the sea domain and invades an urban area when reaching the coast and overtopping 
the shore protection furniture. Note that these five types of origin of the water can be unique or coupled with each other, as for some UR \& SO cases in Table 1 (ID 19, 20, 22, 23).

The diversity of the analysed flow patterns (columns 2, 5 and 7 in Table 1) emphasizes the complexity of urban flood processes, involving subcritical and supercritical flow regimes, openchannel and pressurized flow, both at the surface or in the underground system, interacting with obstacles, building blocks etc. Among the 45 reported studies, very few address identical flow patterns. The experimental set-ups reproduce either a synthetic urban area (highly simplified streets, $90^{\circ}$ intersections and impervious rectangular buildings) or a simplified version of a real city (reproducing the topology of the city but with a highly simplified representation of the facades and street profiles) or finally a more realistic representation of an urban district based on the field DEM (with each individual building being included).

The location of the set-up is indicated to help the reader contact the research team responsible for the flume (columns 3 and 4 in Table 1). It also reveals that the experiments were performed in 17 different countries, confirming the global interest for urban flood experimental data.

Columns 6 and 10 in Table 1 provide the typical dimensions of the laboratory model. A plausible scale factor was derived, by assuming a typical street width equal to $15 \mathrm{~m}$ and a gully width of $60 \mathrm{~cm}$ at the prototype scale. Some set-ups aim at analysing in detail local flow features (e.g. flow in a street intersection, single vertical exchange structure, flow around one isolated building ...), while others focus on larger scale flow characteristics, such as the flow in a street-network, but with a lower spatial resolution and measurement accuracy. As a consequence, the scale factor of models of street intersections or vertical exchange works typically ranges between $1 / 10$ and $1 / 50$, while those of experiments covering an entire urban district or a grid of obstacles range between $1 / 30$ and $1 / 200$. The experiments of Herbich and Shulits (1964) correspond to the largest model extent for tests involving a grid of obstacles. The largest models of urban districts are those of (Ishigaki et al., 2003; Güney et al., 2014), with a setup length of $20 \mathrm{~m}$ and $16 \mathrm{~m}$, respectively, representing real-world urban areas of $3 \mathrm{~km}$ and $2.4 \mathrm{~km}$ in length. 
data. The measured data strongly depend on the scale of the experiment. For very local flow patterns, such as flows in street intersections and vertical exchange structures (blocks I and II in Table 1), spatially distributed flow characteristics are generally available, including 3D velocity fields and 2D water depth fields, together with more global flow variables such as discharges in the different branches. Moreover, for these local flow pattern experiments, the number of tested configurations remains low (below 10) when spatially distributed data were recorded; whereas it reaches up to 200 configurations when only the discharges were recorded. For the experiments investigating larger scale flow patterns such as obstacle grids and urban districts, spatially distributed data are rare and mostly local velocities and water depths were recorded with pointwise measurement tools, except for surface velocity fields derived in some cases from large scale particle image velocimetry (using a camera located above the experimental setup).

Overall, Table 1 demonstrates the availability of rich laboratory datasets covering a broad spectrum of typical urban flood conditions. In the following, we distinguish between the flow processes comprehensively studied and those calling for more laboratory investigations.

\section{Advances of urban flood processes analysis}

By listing the existing experimental datasets, Sect. 2 reveals that a wide range of flow processes were reproduced experimentally. Here, we attempt to present an inventory of the main flow processes of engineering relevance in urban flood studies (Table 2), and to relate them to the works listed in Table 1. This enables assessing whether the existing experimental datasets are comprehensive enough for the validation of the representation of each flow process in numerical models. Table 2 suggests that experimental datasets do exist for most urban flow processes of interest; but not for all of them. Regarding the origin of water, most common flood origins were reproduced experimentally. The main deficiency is the intrusion of water waves from a storm surge, with the water from the sea, overtopping the protection dikes and invading coastal cities with very unsteady flows, as described by Maspataud et al. (2013). One main question is the evolution of the unsteadiness as the flow propagates 
within the urban areas, merges or splits at crossroads and in open spaces: will the typical hydrograph time-scale increase or decrease compared to the surge hydrograph? The validation of numerical simulations certainly requires dedicated experimental data. Moreover, the knowledge on intrusion of water through direct rain on the city domain should be further improved. In particular, as the rain falls on the buildings roofs, part of the water reaches the sewer network (through the gutters) and the rest reaches the surrounding streets or gardens (with possible infiltration) with some surface runoff on the private slots. These processes, computed by Pons et al. (2005) and Paquier and Bazin (2014), still require high quality data to enable deriving empirical parametrizations specific to urban catchments. Future research should also consider the complex coupling between several flood origins.

Numerous datasets of flows in street networks (or within arrays of buildings) were published in the recent years. These consider steady or unsteady flows, including steep hydrographs, at single or multiple street intersections. One main deficiency regarding surface flow corresponds to the consideration of obstacles present in the streets (Mignot et al., 2013) and steep urban areas where mostly supercritical flow conditions take place. In such cases, hydraulic jumps occur at the street intersections (Mignot et al., 2008) and in the vicinity of obstacles (Bazin et al., 2017).

Although the flow in street networks has been deeply studied experimentally, it is not the case of the flow invading other compartments of the urban fabric:

- vertical flow interaction between the underground sewer and the street surface was investigated locally, at the level of one exchange structure or a single street, but it remains undocumented at the level of an entire urban district;

- similarly, data on flow exchanges between the streets and the blocks / slots (building blocks, gardens, hospitals, etc...) through openings (gates, doors, windows...) remain scarce, both at the local level (one facade, one building) and at the district level, while such calculations have been performed for already some time (Hingray et al., 2000; Inoue et al., 2000).

Existing experimental works focused not only on the flow dynamics; but so-called "associated events" have also been considered due to their importance for operational flood risk management. For instance, much attention has been paid to the stability and safety of human beings and cars within 
flooded streets. These valuable experiments enable estimating, from the hydrodynamics, the level of risk for citizens and goods in flooded urban areas. Nevertheless, the behaviour of transported cars or other mobile furniture (either floating or within the water column) in a street network, and the possibility of creating dams at crossroads or street contractions (Mignot et al., 2006b) was not yet investigated in laboratory experiments. Also, experiments on people evacuation were conducted at a single institution (DRPI, Kyoto, Japan) and reproducing similar measurements is desirable. Measurements of hydrodynamic forces on buildings or facades, and the transport of sediments in flooded urban areas have received relatively little attention up to now. Finally, neither the access of rescue vehicles through flooded streets, nor the dispersion of pollutants (e.g. from flooded industry or damaged trucks) within a street network have been tested. Improved numerical modelling of these "associated events" would be of substantial added-value for the management of urban flood risk, but this still requires additional experimental data for model development and validation.

\section{Conclusion}

Based on the analysis of 45 laboratory studies and the identification of the main flow processes of significance in urban flooding, the previous sections have highlighted the need for additional (ambitious) experimental efforts to support the development and validation of more realistic computational models of urban floods. This is particularly the case as next-generation urban flood simulations should not only accurately replicate the water flows but also include the so-called associated events (Sect. 3).

Indeed, as shown in Table 1 and Table 2, validation data are available for assessing most types of numerical models commonly used in engineering and research to simulate urban floods, namely (upper part of Table 3):

- 2D-SWE, or the 2D-SWE coupled with a porosity model, or the coupled 1D (in the streets) and 2D (in the crossroads) SWE, to compute surface flow in the urban area; 
- coupled 2D-SWE (in the streets) and 1D-SWE (in the sewer network), along with exchange models, to compute the coupled flows in both the underground and surface layers of the urban area;

- 2D-SWE or Boussinesq-type equations to compute long and/or short waves approaching the shore and invading coastal urban areas;

- 3D Reynolds-averaged Navier-Stokes equations at the level of an isolated building (Gems et al., 2016) or a single street intersection (Ghostine et al., 2009).

In contrast, more advanced numerical models (lower part of Table 3) are required to represent the "associated events" occurring during urban floods, for which dedicated experimental data are virtually unavailable. For instance, empirical or semi-analytical parametrizations are required to estimate the amount of water entering the buildings or blocks, for computing sediment and pollutant transport in urban environments, or entrainment of pieces of urban furniture within a flooded network of streets. Similarly, specific numerical developments are needed for computing the behaviour of rescue vehicles, citizen evacuation, etc. using agent based approaches.

The authors recommend that future experimental research aims at getting more quantitative insights into these associated processes closely intertwined with flow behaviour during urban flooding. High quality experimental observations of these processes will contribute to unlock key bottlenecks in the current modelling practice and, consequently, pave the way for more integrative analyses of the urban water and anthropic systems under (extreme) flooding conditions.

\section{References}

Abt, S.R., Wittier, R.J., Taylor, A., Love, D.J., 1989. Human stability in a high flood hazard zone. Journal of the American Water Resources Association 25(4), 881-890.

Apel, H., Martinez Trepat, O., Nghia Hung, N., Thi Chinh, D., Merz, B., Viet Dung, N., 2016. Combined fluvial and pluvial urban flood hazard analysis: Concept development and application to Can Tho city, Mekong Delta, Vietnam. Natural Hazards and Earth System Sciences 16(4), 941-961.

Arrault, A., Finaud-Guyot, P., Archambeau, P., Bruwier, M., Erpicum, S., Pirotton, M., Dewals, B., 2016. Hydrodynamics of long-duration urban floods: hacknewline experiments and numerical modelling. Natural Hazards and Earth System Sciences 16(6), 1413-1429.

Baba, Y., Ishigaki, T., Toda, K., 2017. Experimental studies on safety evacuation from underground spaces under inundation situations. Journal of JSCE 5(1), 269-278. 
Barkdoll, B.D., Hagen, B.L., Odgaard, A.J., 1998. Experimental comparison of dividing open-channel with duct flow in T-junction. Journal of Hydraulic Engineering 124(1), 92-95.

Bazin, P.-H., Mignot, E., Paquier, A., 2017. Computing flooding of crossroads with obstacles using a 2D numerical model. Journal of Hydraulic Research 55(1), 72-84.

Bazin, P.-H., Nakagawa, H., Kawaike, K., Paquier, A., Mignot, E., 2014. Modeling flow exchanges between a street and an underground drainage pipe during urban floods. Journal of Hydraulic Engineering 140(10), 04014051.

Beg, M.N.A., Carvalho, R.F., Leandro, J., 2017. Effect of surcharge on gully-manhole flow. Journal of Hydroenvironment Research. In press.

Beretta, R., Ravazzani, G., Maiorano, C., Mancini, M., 2018. Simulating the Influence of Buildings on Flood Inundation in Urban Areas. Geosciences 8(2), 77.

Bernardini, G., Postacchini, M., Quagliarini, E., Brocchini, M., Cianca, C., D’Orazio, M., 2017. A preliminary combined simulation tool for the risk assessment of pedestrians' flood-induced evacuation. Environmental Modelling \& Software 96, 14-29.

Bruwier, M., Archambeau, P., Erpicum, S., Pirotton, M., Dewals, B., 2017. Shallow-water models with anisotropic porosity and merging for flood modelling on Cartesian grids. Journal of Hydrology 554, 693-709.

Cea, L., Garrido, M., Puertas, J., 2010. Experimental validation of two-dimensional depth-averaged models for forecasting rainfall-runoff from precipitation data in urban areas. Journal of Hydrology 382(1), 88-102.

Creëlle, S., Engelen, L., Schindfessel, L., Cunha Ramos, P., De Mulder, T., 2017. Experimental investigation of free surface gradients in a $90^{\circ}$ angled asymmetrical open channel confluence, Advances Hydroinformatics. Sophia Antipolis, pp. 803-819.

Chen, Y., Zhou, H., Zhang, H., Du, G., Zhou, J., 2015. Urban flood risk warning under rapid urbanization, Environmental Research, 139, 3-10.

Despotovic, J., Plavsic, J., Stefanovic, N., Pavlovic, D., 2005. Inefficiency of storm water inlets as a source of urban floods. Water Science and Technology 51(2), 139-145.

Dottori F et al. (2013) Detailed data is welcome, but with a pinch of salt: Accuracy, precision, and uncertainty in flood inundation modeling. Water Resources Research 49(9), 6079-6085.

ElKadi, K., Lewicki, L., Paquier, A., Rivière, N., Travin, G., 2011. Division of critical flow at three-branch open-channel intersection. Journal of Hydraulic Research 49(2), 231-238.

Falconer, R., Xia, J., Liang, D., Kvocka, D., 2017. Flood Modelling and harzard assessment for extreme events in riverine basins, in: Proceedings 37th IAHR World Congress.

Fang, Q., 2016. Adapting Chinese cities to climate change. Science 354(6311), 425-426.

Finaud-Guyot, P., Garambois, P.-A., Araud, Q., Lawniczak, F., François, P., Vazquez, J., Mosé, R., 2018. Experimental insight for flood flow repartition in urban areas. Urban Water Journal 15(3), 1-9.

Fraga, I., Cea, L., Puertas, J., 2017. Validation of a 1D-2D dual drainage model under unsteady part-full and surcharged sewer conditions. Urban Water Journal 14(1), 74-84.

Gems, B., Mazzorana, B., Hofer, T., Sturm, M., Gabl, R., Aufleger, M., 2016. 3-D hydrodynamic modelling of flood impacts on a building and indoor flooding processes. Natural Hazards and Earth System Sciences 16(6), 1351-1368.

Ghostine, R., Hoteit, I., Vazquez, J., Terfous, A., Ghenaim, A., Mose, R., 2015. Comparison between a coupled 1D-2D model and a fully 2D model for supercritical flow simulation in crossroads. Journal of Hydraulic Research 53(2), 274-281.

Ghostine, R., Kesserwani, G., Vazquez, J., Rivière, N., Ghenaim, A., Mose, R., 2009. Simulation of supercritical flow in crossroads: Confrontation of a $2 \mathrm{D}$ and $3 \mathrm{D}$ numerical approaches to experimental results. Computers \& Fluids 38(2), 425-432.

Glenis, V., McGough, A.-S., Kutija, V., Kilsby, C., Woodman, S., 2013. Flood modelling for cities using Cloud computing. Journal of Cloud Computing: Advances, Systems and Applications 2(1), 7.

Goseberg, N., 2013. Reduction of maximum tsunami run-up due to the interaction with beachfront development - application of single sinusoidal waves. Natural Hazards and Earth System Sciences 13(11), 29913010 .

Guillen-Ludena, S., D. Lopez, N. Riviere, Mignot, E., 2017. Extreme flood flow in an increasingly urbanized floodplain: an experimental approach. 37th IAHR world congress, in: Theme(2) Flood Management, KualaLumpur, Malaysia.

Güney, M.S., Tayfur, G., Bombar, G., Elci, S., 2014. Distorted Physical Model to Study Sudden Partial Dam Break Flows in an Urban Area. Journal of Hydraulic Engineering 140(11), 05014006.

Hager, W.H., 1989a. Supercritical flow in channel junctions. Journal of Hydraulic Engineering 115(5), 595-616. Hager, W.H., 1989b. Transitional flow in channel junctions. Journal of Hydraulic Engineering 115(2), 243-259. 
Herbich, J.B., Shulits, S., 1964. Large-scale roughness in open-channel flow, in: Proceedings Amercian Society Civil Engineers 90(HY6).

Hingray, B., Cappelaere, B., Bouvier, C., Desbordes, M., 2000. Hydraulic vulnerability of elementary urban cell. Journal of Hydrologic Engineering 5(4), 402-410.

Huang, C.-J., Hsu, M.-H., Teng, W.-H., Wang, Y.-H., 2014. The Impact of Building Coverage in the Metropolitan Area on the Flow Calculation. Water 6(8), 2449-2466.

Ishigaki, T., Keiichi, T., Kazuya, I., 2003. Hydraulic model tests of inundation in urban area with underground space. Theme B, Proc. of XXX IAHR Cogress, Greece.

Ishigaki, T., Y. Asai, Y.O. ans, Toda, K., Shimada, H., 2008. Evacuation criteria during urban flooding in underground space. Proc. of 11 th Conference on Urban Drainage, Edinburgh, Scotland, UK.

Inoue, K. Kawaike, K., Hayashi, H., 2000. Numerical simulation models of inundation flow in urban area. J. Hydrosci. Hyd. Engng 18(1), 119-126.

Isidoro, J.M.G.P., Lima, J.L.M.P. de, Leandro, J., 2013. The study of rooftop connectivity on the rainfall-runoff process by means of a rainfall simulator and a physical model. Zeitschrift für Geomorphologie, Supplementary Issues 57(1), 177-191.

JinNoh, S., Lee, S., An, H., Kawaike, K., Nakagawa, H., 2016. Ensemble urban flood simulation in comparison with laboratory-scale experiments: Impact of interaction models for manhole, sewer pipe, and surface flow. Advances in Water Resources 97, 25-37.

Kim, B., Sanders, B.F., Famiglietti, J.S., Guinot, V., 2015. Urban flood modeling with porous shallow-water equations: A case study of model errors in the presence of anisotropic porosity. Journal of Hydrology $523,680-692$.

Kreibich H., van den Bergh, J.C.J.M., Bouwer, L.M., Bubeck, P., Ciavola, P., Green, C., Hallegatte, S., Logar, I., Meyer, V., Schwarze, R., Thieken, A.H., 2014. Costing natural hazards. Nat Clim Change 4(5), 303306.

Kvocka, D., Falconer, R.A., Bray, M., 2016. Flood hazard assessment for extreme flood events. Natural Hazards 84(3), 1569-1599.

LaRocque, L.A., Elkholy, M., Chaudhry, M.H., Imran, J., 2013. Experiments on urban flooding caused by a levee breach. Journal of Hydraulic Engineering 139(9), 960-973.

Leandro, J., Carvalho, R., Martins, R., 2010. Experimental scaled-model as a benchmark for validation of urban flood models. Novatech, GRAIE, Lyon, France.

Leandro, J., Chen, A.S., Djordjevic, S., Savic, D.A., 2009. Comparison of 1D/1D and 1D/2D coupled (sewer/surface) hydraulic models for urban flood simulation. Journal of Hydraulic Engineering 135(6), 495-504.

Lee, S., Nakagama, H., Kawaike, K., Zhang, H., 2012. Study on inlet discharge coefficient through the different shapes of storm drains for urban inundation analysis. Journal of Japan Society of Civil Engineers, Ser. B1 (Hydraulic Engineering) 68(4), I_31-I_36.

Lhomme. J., Soares-Frazão. S., Guinot. V., Zech̆. y., 2007. Modélisation à grande échelle des inondations urbaines et modèle 2D à porosité. La Houille Blanche 4, 104-110.

Liu, L., Sun, J., Lin, B., Lu, L., 2018. Building performance in dam-break flow - an experimental study. Urban Water Journal 15(3), 251-258.

Lopes, P., Carvalho, R.F., Leandro, J., 2017. Numerical and experimental study of the fundamental flow characteristics of a 3D gully box under drainage. Water Science and Technology 75(9), 2204-2215.

Mark, O., Weesakul, S., Apirumanekul, C., Aroonnet, S.B., Djordjevic, S., 2004. Potential and limitations of 1D modelling of urban flooding. Journal of Hydrology 299(3), 284-299.

Martínez-Gomariz, E., Gómez, M., Russo, B., 2016. Experimental study of the stability of pedestrians exposed to urban pluvial flooding, Natural Hazards 82(2), 1259-1278.

Martínez-Gomariz, E., Gómez, M., Russo, B., Djordjevic, S., 2017. A new experiments-based methodology to define the stability threshold for any vehicle exposed to flooding, Urban Water Journal 14 (9), 930-939

Martínez-Gomariz, E., Gómez, M., Russo, B., Djordjevic, S., 2018. Stability criteria for flooded vehicles: a state-of-the-art review. Journal of Flood Risk Management 11(S2), S817-S826.

Martins, R., Kesserwani, G., Rubinato, M., Lee, S., Leandro, J., Djordjević, S., Shucksmith, J. D., 2017. Validation of 2D shock capturing flood models around a surcharging manhole. Urban Water Journal, 14(9), 892-899.

Maspataud, A., Ruz, M.-H., Vanhée, S., 2013. Potential impacts of extreme storm surges on a low-lying densely populated coastline: the case of Dunkirk area, Northern France. Natural Hazards 66(3), 1327-1343.

Mignot, E., Bonakdari, H., Knothe, P., Kouyi, G.L., Bessette, A., Rivière, N., Bertrand-Krajewski, J.-L., 2012. Experiments and 3D simulations of flow structures in junctions and their influence on location of flowmeters. Water Science and Technology 66(6), 1325-1332. 
Mignot, E., Paquier, A., Ishigaki, T., 2006a. Comparison of numerical and experimental simulations of a flood in a dense urban area. Water Science and Technology 54(6-7), 65-73.

Mignot E., Paquier A., Haider S., 2006b. Modeling floods in a dense urban area using 2D shallow water equations. Journal of Hydrology 327 (1-2), 186-199.

Mignot, E., Rivière, N., Perkins, R.J., Paquier, A., 2008. Flow patterns in a four-branch junction with supercritical flow. Journal of Hydraulic Engineering 134(6), 701-713.

Mignot, E., Rivière, N., Perkins, R.J., Paquier, A., Travin, G., 2009. Closure of flow patterns in a four branch junction with supercritical flow. Journal of Hydraulic Engineering 135(11), 1023-1024.

Mignot, E., Zeng, C., Dominguez, G., Li, C.-W., Rivière, N., Bazin, P.-H., 2013. Impact of topographic obstacles on the discharge distribution in open-channel bifurcations. Journal of Hydrology 494, 10-19.

Nanía, L.S., Gómez, M., Dolz, J., 2004. Experimental study of the dividing flow in steep street crossings. Journal of Hydraulic Research 42(4), 406-412.

Nanía, L.S., Gómez, M., Dolz, J., Comas, P., Pomares, J., 2011. Experimental Study of Subcritical Dividing Flow in an Equal-Width, Four-Branch Junction. Journal of Hydraulic Engineering 137(10), 1298-1305.

Nanía, L.S., Gonzalo, R., Gómez, M., 2014. Influence of Channel Width on Flow Distribution in Four-Branch Junctions with Supercritical Flow: Experimental Approach. Journal of Hydraulic Engineering 140(1), $77-88$.

Neal, J.C., Bates, P.D., Fewtrell, T.J., Hunter, N.M., Wilson, M., Horritt, M.S., 2009. Distributed whole city water level measurements from the Carlisle 2005 urban flood event and comparison with hydraulic model simulations. Journal of Hydrology 368(1), 42-55.

Ozdemir, H., Sampson, C.C., Almeida, G.A.M. de, Bates, P.D., 2013. Evaluating scale and roughness effects in urban flood modelling using terrestrial LIDAR data. Hydrology and Earth System Sciences 17(10), 4015-4030.

Paquier, A., Bazin, P.H., 2014. Estimating uncertainties for urban floods modelling. La Houille Blanche 6, 1318.

Paquier, A., Mignot, E., Bazin, P.-H., 2015. From Hydraulic Modelling to Urban Flood Risk. Procedia Engineering 115, 37-44.

Park, H., Cox, D.T., Lynett, P.J., Wiebe, D.M., Shin, S., 2013. Tsunami inundation modeling in constructed environments: A physical and numerical comparison of free-surface elevation, velocity, and momentum flux. Coastal Engineering 79, 9-21.

Pons, F., Zhang, B., Sergent, P., Feltz, D., 2005. Simulation of flash floods in Marseille and Bordeaux with a two-dimensional runoff model, in $10^{\text {th }}$ International Conference of Urban Drainage. Copenhagen, Denmark.

Rivière, N., Travin, G., Perkins, R.J., 2011. Subcritical open channel flows in four branch intersections. Water Resources Research 47(10), 2011 WR010504.

Rivière, N., Travin, G., Perkins, R.J., 2014. Transcritical flows in three and four branch open-channel intersections. Journal of Hydraulic Engineering 140(4), 04014003.

Rivière, N., Xiao, M., Perkins, R.J., Travin, G., 2018. Supercritical flow expansion in an open channel bifurcation. In review at Journal of Hydraulic Research.

Rodi, W., 2017. Turbulence modeling and simulation in hydraulics: a historical review. Journal of Hydraulic Engineering 143(5), 03117001.

Romagnoli, M., Carvalho, R., Leandro, J., 2013. Turbulence characterization in a gully with reverse flow. Journal of Hydraulic Engineering 139(7), 736-744.

Rubinato, M., Martins, R., Kesserwani, G., Leandro, J., Djordjevic, S., Shucksmith, J., 2017. Experimental calibration and validation of sewer/surface flow exchange equations in steady and unsteady flow conditions. Journal of Hydrology 552, 421-432.

Russo, B., Gómez, M., Macchione, F., 2013. Pedestrian hazard criteria for flooded urban areas. Natural Hazards 69(1), 251-265.

Russo, B., Gómez, M., Tellez, J., 2013. Methodology to estimate the hydraulic efficiency of nontested continuous transverse grates. Journal of Irrigation and Drainage Engineering 139(10), 864-871.

Schindfessel, L., Creëlle, S., De Mulder, T., 2015. Flow patterns in an open channel confluence with increasingly dominant tributary inflow. Water 7(9), 4724-4751.

Seyoum, S., Vojinovic, Z., Price, R.K., Weesakul, S., 2012. Coupled 1D and Noninertia 2D Flood Inundation Model for Simulation of Urban Flooding. Journal of Hydraulic Engineering 138(1), 23-34.

Smith L.S., Liang, Q., Quinn, P.F., 2015. Towards a hydrodynamic modelling framework appropriate for applications in urban flood assessment and mitigation using heterogeneous computing. Urban Water Journal 12(1), 67-78.

Smith, G.P., Rahman, P.F., Wasko, C., 2016. A comprehensive urban floodplain dataset for model benchmarking. International Journal of River Basin Management 14(3), 345-356. 
Soares-Frazão, S., Zech, Y., 2008. Dam-break flow through an idealised city. Journal of Hydraulic Research 46(5), 648-658.

Sturm, M., Gems B., Keller F. Mazzorana B. Fuchs S. Papathoma-Köhle M., M., A., 2018. Experimental measurements of flood-induced impact forces on exposed elements, in: Proceedings RiverFlow 2018 conference.

Takayama, T., Takara, K., Toda, K., Fujita, M., Mase, H., Tachikawa, Y., Yoneyama, N., Tsutsumi, D., T. Yasuda, Sayama, T., 2007. Research works for risk assessment technology related to flood in urban area. Annuals of Disas. Prev. Res. Inst., Kyoto Univ., No. 50 C.

Teng, J., Jakeman, A.J., Vaze, J., Croke, B.F.W., Dutta, D., Kim, S., 2017. Flood inundation modelling: A review of methods, recent advances and uncertainty analysis. Environmental Modelling \& Software 90, 201-216.

Testa, G., Zuccala, D., Alcrudo, F., Mulet, J., Soares-Frazão, S., 2007. Flash flood flow experiment in a simplified urban district. Journal of Hydraulic Research 45(sup1), 37-44.

Tomiczek, T., Prasetyo, A., Mori, N., Yasuda, T., Kennedy, A., 2016. Physical modelling of tsunami onshore propagation, peak pressures, and shielding effects in an urban building array. Coastal Engineering 117 , 97-112.

UNISDR, 2015. The human cost of weather related disasters, CRED 1995-2015, Unites Nations, Geneva.

Van Ootegem, L., Van Herck, K., Creten, T., Verhofstadt, E., Foresti, L., Goudenhoofdt, E., Reyniers, M., Delobbe, L., Murla Tuyls, D., Willems, P., 2016. Exploring the potential of multivariate depth-damage and rainfall-damage models. Journal of Flood Risk Management 11(S2), S916-S929.

Velickovic, M., Zech, Y., Soares-Frazão, S., 2017. Steady-flow experiments in urban areas and anisotropic porosity model. Journal of Hydraulic Research 55(1), 85-100.

Wang, H., Mostafizi, A., Cramer, L.A., Cox, D., Park, H., 2016. An agent-based model of a multimodal nearfield tsunami evacuation: Decision-making and life safety. Transportation Research Part C: Emerging Technologies 64, 86-100.

Weber, L.J., Schumate, E.D., Mawer, N., 2001. Experiments on flow at a $90^{\circ}$ open-channel junction. Journal of Hydraulic Engineering 127(5), 340-350.

Xia, J., Falconer, R.A., Wang, Y., Xiao, X., 2014. New criterion for the stability of a human body in floodwaters. Journal of Hydraulic Research 52(1), 93-104.

Yasuda, T., Hiraishi, T., 2004. Experimental Study of Tsunami Inundation in Coastal Urban Area, in: Proceedings of the Fourteenth International Offshore Polar Engineering Conference.

Zhou, Q., Yu, W., Chen, A.S., Jiang, C., Fu, G., 2016. Experimental Assessment of Building Blockage Effects in a Simplified Urban District. Procedia Engineering 154, 844-852. 
Table 1: Databases available in literature for validation of urban flood numerical models

457

458

Table 2: Urban flood processes and corresponding data availability for validation

459

460

Table 3: Typology of numerical models applied to compute urban flood events

461 
Table 1: Databases available in literature for validation of urban flood numerical models

\begin{tabular}{|c|c|c|c|c|c|c|c|c|c|c|}
\hline $\begin{array}{l}\text { Water } \\
\text { origin } \\
\text { (I) }\end{array}$ & Flow pattern & Location of set-up & Reference & $\begin{array}{l}\text { Additional } \\
\text { remarks }\end{array}$ & $\begin{array}{l}\text { Length of } \\
\text { set-up (m) }\end{array}$ & $\begin{array}{l}\text { Steady (S)/ } \\
\text { Unsteady (U) }\end{array}$ & 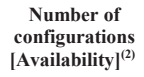 & Types of data & Scale factors ${ }^{(3)}$ & ID \\
\hline \multicolumn{11}{|c|}{ I Flow at street intersections } \\
\hline \multirow{4}{*}{ UR } & \multirow{4}{*}{$\begin{array}{l}\text { 3-branch subcritical } \\
\text { junction }\end{array}$} & $\begin{array}{l}\text { INSA/LMFA } \\
\text { (Lyon, France) }\end{array}$ & $\begin{array}{l}\text { Mignot et al. } \\
\text { (2012) }\end{array}$ & & 5 & $\mathrm{~s}$ & $1[\mathrm{~B}]$ & $3 \mathrm{D}$ velocity field & $\begin{array}{l}\mathrm{S}_{\mathrm{W}}=0.3 \mathrm{~m} \\
\mathrm{SF} \sim 1 / 50\end{array}$ & (1) \\
\hline & & IIHR (Iowa, USA) & $\begin{array}{l}\text { Weber et al. } \\
\text { (2001) }\end{array}$ & & 22 & $\mathrm{~s}$ & $6[\mathrm{~A}]$ & 3D velocity field & $\begin{array}{l}\mathrm{S}_{\mathrm{W}}=0.91 \mathrm{~m} \\
\mathrm{SF} \sim 1 / 16\end{array}$ & (2) \\
\hline & & $\begin{array}{l}\text { Gent University } \\
\text { (Gent, Belgium) }\end{array}$ & $\begin{array}{l}\text { Schindfessel et al. } \\
\quad(2015)\end{array}$ & $\begin{array}{l}\text { Rectangular } \\
\text { sections with } \\
\text { chamfers }\end{array}$ & 33 & S & $2[\mathrm{D}]$ & $3 \mathrm{D}$ velocity field & $\begin{array}{l}\mathrm{S}_{\mathrm{W}}=0.98 \mathrm{~m} \\
\mathrm{SF} \sim 1 / 15\end{array}$ & (3) \\
\hline & & $\begin{array}{l}\text { Gent University } \\
\text { (Gent, Belgium) }\end{array}$ & $\begin{array}{l}\text { Creëlle et al. } \\
\text { (2017) }\end{array}$ & & 12 & $\mathrm{~S}$ & $6[\mathrm{D}]$ & Water depth field & $\begin{array}{l}\mathrm{S}_{\mathrm{W}}=0.4 \mathrm{~m} \\
\mathrm{SF} \sim 1 / 38\end{array}$ & (4) \\
\hline UR & $\begin{array}{l}3 \text { branch transcritical and } \\
\text { supercritical junction }\end{array}$ & $\begin{array}{l}\text { EPFL (Lausanne, } \\
\text { Switzerland) }\end{array}$ & $\begin{array}{c}\text { Hager (1989a \& } \\
1989 \mathrm{~b})\end{array}$ & & 2 & $\mathrm{~S}$ & $8[\mathrm{~A}] \&[\mathrm{C}]$ & 2D velocity field & $\begin{array}{l}\mathrm{S}_{\mathrm{W}}=0.099 \mathrm{~m} \\
\mathrm{SF} \sim 1 / 152\end{array}$ & (5) \\
\hline \multirow[t]{2}{*}{ UR } & \multirow[t]{2}{*}{$\begin{array}{l}\text { 3-branch subcritical } \\
\text { bifurcation }\end{array}$} & $\begin{array}{l}\text { INSA/LMFA } \\
\text { (Lyon, France) }\end{array}$ & $\begin{array}{l}\text { Mignot et al. } \\
\quad(2013)\end{array}$ & $\begin{array}{l}\text { Without/with } 10 \\
\text { obstacles (urban } \\
\text { furniture) }\end{array}$ & 5 & S & $\begin{array}{l}14 \text { flows } \\
\times 10 \text { obstacles } \\
\text { [D] }\end{array}$ & $\begin{array}{c}\text { * Flow discharge } \\
+2 \mathrm{D} \text { velocity field (for } 1 \\
\text { flow with } 10 \text { obstacle } \\
\text { configs.) }\end{array}$ & $\begin{array}{l}\mathrm{S}_{\mathrm{W}}=0.3 \mathrm{~m} \\
\mathrm{SF} \sim 1 / 50\end{array}$ & (6) \\
\hline & & IIHR (Iowa, USA) & $\begin{array}{l}\text { Barkdoll et al. } \\
(1998)\end{array}$ & & 2.7 & $\mathrm{~S}$ & $1[\mathrm{C}]$ & $\begin{array}{l}\text { 2D velocity field \& water } \\
\text { depth field }\end{array}$ & $\begin{array}{l}\mathrm{S}_{\mathrm{W}}=0.152 \mathrm{~m} \\
\mathrm{SF} \sim 1 / 100\end{array}$ & (7) \\
\hline \multirow[t]{2}{*}{ UR } & \multirow{2}{*}{$\begin{array}{l}\text { 3-branch critical \& } \\
\text { supercritical bifurcation }\end{array}$} & $\begin{array}{l}\text { INSA/LMFA } \\
\text { (Lyon, France) }\end{array}$ & $\begin{array}{l}\text { ElKadi et al. } \\
(2011)\end{array}$ & & 5 & S & $\sim 100[\mathrm{~B}]$ & $\begin{array}{l}\text { Discharge distribution to the } \\
\text { downstream branches } \\
+ \text { water depth field for } 1 \text { flow }\end{array}$ & $\begin{array}{l}\mathrm{S}_{\mathrm{W}}=0.3 \mathrm{~m} \\
\mathrm{SF} \sim 1 / 50\end{array}$ & (8) \\
\hline & & $\begin{array}{l}\text { INSA/LMFA } \\
\text { (Lyon, France) }\end{array}$ & $\begin{array}{l}\text { Rivière et al. } \\
(2018)\end{array}$ & & 5 & $\mathrm{~S}$ & $62[\mathrm{~B}]$ & $\begin{array}{l}\text { Discharge distribution and } \\
\text { water depth fields }\end{array}$ & $\begin{array}{l}\mathrm{S}_{\mathrm{W}}=0.3 \mathrm{~m} \\
\mathrm{SF} \sim 1 / 50\end{array}$ & (9) \\
\hline \multirow{2}{*}{ UR } & \multirow{2}{*}{$\begin{array}{l}\text { 4-branch subcritical } \\
\text { intersection }\end{array}$} & $\begin{array}{l}\text { INSA/LMFA } \\
\text { (Lyon, France) }\end{array}$ & $\begin{array}{l}\text { Rivière et al. } \\
\text { (2011) }\end{array}$ & & 5 & $\mathrm{~s}$ & $220[\mathrm{~B}]$ & $\begin{array}{l}\text { Discharge distribution to the } \\
\text { downstream branches }\end{array}$ & $\begin{array}{l}\mathrm{S}_{\mathrm{W}}=0.3 \mathrm{~m} \\
\mathrm{SF} \sim 1 / 50\end{array}$ & (10) \\
\hline & & $\begin{array}{l}\text { UPC (Barcelona, } \\
\text { Spain) }\end{array}$ & $\begin{array}{l}\text { Nanía et al. } \\
\quad(2011)\end{array}$ & & 8.5 & $\mathrm{~S}$ & $159[\mathrm{~A}]$ & $\begin{array}{l}\text { Discharge distribution to the } \\
\text { downstream branches }\end{array}$ & $\begin{array}{l}\mathrm{S}_{\mathrm{W}}=1.5 \mathrm{~m} \\
\mathrm{SF} \sim 1 / 10\end{array}$ & (11) \\
\hline \multirow{3}{*}{ UR } & \multirow{3}{*}{$\begin{array}{l}\text { 4-branch transcritical \& } \\
\text { supercritical flows }\end{array}$} & $\begin{array}{l}\text { INSA/LMFA } \\
\text { (Lyon, France) }\end{array}$ & $\begin{array}{l}\text { Rivière et al. } \\
\text { (2014) }\end{array}$ & & 5 & $\mathrm{~S}$ & $113[\mathrm{~B}]$ & $\begin{array}{l}\text { Discharge distribution to the } \\
\text { downstream branches }\end{array}$ & $\begin{array}{l}\mathrm{S}_{\mathrm{W}}=0.3 \mathrm{~m} \\
\mathrm{SF} \sim 1 / 50\end{array}$ & (12) \\
\hline & & $\begin{array}{l}\text { INSA/LMFA } \\
\text { (Lyon, France) }\end{array}$ & $\begin{array}{l}\text { Mignot et al. } \\
\text { (2009) \& Mignot } \\
\text { et al. }(2008)\end{array}$ & & 4.5 & S & $\begin{array}{c}200 \\
{[\mathrm{~B}] \&[\mathrm{~B}]}\end{array}$ & $\begin{array}{l}\text { Discharge distributions to the } \\
\text { downstream branches } \\
+8 \text { water depth fields }\end{array}$ & $\begin{array}{l}\mathrm{S}_{\mathrm{W}}=0.3 \mathrm{~m} \\
\mathrm{SF} \sim 1 / 50\end{array}$ & (13) \\
\hline & & $\begin{array}{l}\text { UPC (Barcelona, } \\
\text { Spain) }\end{array}$ & $\begin{array}{l}\text { Nanía et al. } \\
\text { (2004) \& Nanía et } \\
\text { al. (2014) }\end{array}$ & & 8.5 & S & $\begin{array}{c}\sim 200 \\
{[\mathrm{~B}] \&[\mathrm{~B}]}\end{array}$ & $\begin{array}{l}\text { Discharge distribution to the } \\
\text { downstream branches }\end{array}$ & $\begin{array}{l}\mathrm{S}_{\mathrm{W}}=1.5 \mathrm{~m} \\
\mathrm{SF} \sim 1 / 10\end{array}$ & (14) \\
\hline \multicolumn{11}{|c|}{ II Vertical exchanges (street/sewage) } \\
\hline SO & $\begin{array}{l}1 \text { overflow exchange } \\
\text { structure (1 way: from }\end{array}$ & $\begin{array}{c}\text { University of } \\
\text { Coimbra (Coimbra, }\end{array}$ & $\begin{array}{l}\text { Lopes et al. (2017) } \\
\text { \& Romagnoli et al. }\end{array}$ & & 0.6 & S & $4[\mathrm{~B}] \&[\mathrm{~B}]$ & 3D velocity field & $\begin{array}{c}\mathrm{G}_{\mathrm{W}}=0.6 \mathrm{~m} \\
\mathrm{SF} \sim 1\end{array}$ & (15) \\
\hline
\end{tabular}




\begin{tabular}{|c|c|c|c|c|c|c|c|c|c|c|}
\hline $\begin{array}{l}\text { Water } \\
\text { origin } \\
\text { (1) }\end{array}$ & Flow pattern & Location of set-up & Reference & $\begin{array}{l}\text { Additional } \\
\text { remarks }\end{array}$ & $\begin{array}{l}\text { Length of } \\
\text { set-up (m) }\end{array}$ & $\begin{array}{l}\text { Steady (S)/ } \\
\text { Unsteady (U) }\end{array}$ & 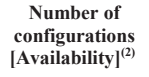 & Types of data & Scale factors ${ }^{(3)}$ & ID \\
\hline & sewer to surface) & $\begin{array}{l}\text { Portugal) } \\
\end{array}$ & (2013) & & & & & & & \\
\hline \multirow{3}{*}{ UR } & \multirow{3}{*}{$\begin{array}{l}1 \text { inlet exchange structure } \\
\text { (1 way: from surface to } \\
\text { sewer) }\end{array}$} & $\begin{array}{l}\text { UPC (Barcelona, } \\
\text { Spain) }\end{array}$ & $\begin{array}{l}\text { Russo, Gómez, and } \\
\text { Tellez (2013) }\end{array}$ & & 5.5 & $\mathrm{~S}$ & $280[\mathrm{~B}]$ & $\begin{array}{l}\text { Exchanged discharge to } \\
\text { sewer }\end{array}$ & $\mathrm{SF}=1$ & (16) \\
\hline & & $\begin{array}{c}\text { Faculty of Civil } \\
\text { Engineering } \\
\text { (Belgrade, Serbia) }\end{array}$ & $\begin{array}{l}\text { Despotovic et al. } \\
(2005)\end{array}$ & $\begin{array}{l}\text { (without and with } \\
\text { clogging effects) }\end{array}$ & 5 & S & $\sim 100[\mathrm{C}]$ & $\begin{array}{c}\text { Exchanged discharge to } \\
\text { sewer }+ \text { flow spreading on } \\
\text { the street }\end{array}$ & $\mathrm{SF} \sim 1$ & (17) \\
\hline & & DPRI (Kyoto, Japan) & Lee et al. (2012) & & 6 & S & $12[\mathrm{~B}]$ & $\begin{array}{l}\text { Exchanged discharge + water } \\
\text { depths }\end{array}$ & $\mathrm{SF}=1 / 10$ & (18) \\
\hline \multirow{2}{*}{$\begin{array}{l}\text { UR \& } \\
\text { SO }\end{array}$} & \multirow{2}{*}{$\begin{array}{c}1 \text { exchange structure } \\
\text { (2 ways between surface } \\
\text { and sewer) }\end{array}$} & $\begin{array}{c}\text { University of } \\
\text { Sheffield (UK) }\end{array}$ & $\begin{array}{l}\text { Rubinato et al. } \\
\text { (2017) \& Martins } \\
\text { et al. (2017) }\end{array}$ & & 8 & $\mathrm{~S}+\mathrm{U}$ & $\begin{array}{c}46 \\
{[\mathrm{~A}] \&[\mathrm{~A}]} \\
\end{array}$ & $\begin{array}{c}\text { Exchanged discharges } \\
\text { (steady }+ \text { time evolution) }+ \\
\text { water depths } \\
\end{array}$ & $\mathrm{SF}=1 / 6$ & (19) \\
\hline & & $\begin{array}{l}\text { U. of Coimbra } \\
\text { (Portugal) }\end{array}$ & Beg et al. (2017) & & 9.5 & S & $19[\mathrm{~B}]$ & $\begin{array}{c}\text { Exchanged discharges }+ \\
\text { velocity fields }+ \text { pressure } \\
\text { heads }\end{array}$ & $\begin{array}{c}\mathrm{G}_{\mathrm{W}}=0.6 \\
\mathrm{SF} \sim 1\end{array}$ & (20) \\
\hline UR & 1 street with several inlets & $\begin{array}{l}\text { U. of Coimbra } \\
\text { (Portugal) }\end{array}$ & $\begin{array}{l}\text { Leandro et al. } \\
(2010)\end{array}$ & & 36 & S & $36[\mathrm{~B}]$ & Exchanged discharge & $\begin{array}{l}\mathrm{S}_{\mathrm{W}}=0.5 \mathrm{~m} \\
\mathrm{~S} \sim 1 / 30\end{array}$ & (21) \\
\hline \multirow{2}{*}{$\begin{array}{l}\text { UR \& } \\
\text { SO }\end{array}$} & \multirow{2}{*}{$\begin{array}{l}1 \text { street with several } \\
\text { exchange structures ( } 2 \\
\text { ways) }\end{array}$} & \multirow{2}{*}{ DPRI (Kyoto, Japan) } & Bazin et al. (2014) & & \multirow{2}{*}{10} & \multirow{2}{*}{$\mathrm{S}+\mathrm{U}$} & $\begin{array}{c}2 \text { steady } \\
2 \text { unsteady } \\
{[C]}\end{array}$ & \multirow{2}{*}{$\begin{array}{l}\text { Water depth and pressure } \\
\text { head along the street }(+ \text { total } \\
\text { exchanged discharge for } \\
\text { Bazin2014) }\end{array}$} & $\begin{array}{l}\mathrm{S}_{\mathrm{w}}=0.8 \mathrm{~m} \\
\mathrm{SF} \sim 1 / 20\end{array}$ & \multirow{2}{*}{$(22)$} \\
\hline & & & $\begin{array}{l}\text { JinNoh et al. } \\
\quad(2016)\end{array}$ & & & & $\begin{array}{c}6 \text { steady } \\
2 \text { unsteady [B] }\end{array}$ & & $\mathrm{SF}=1 / 20$ & \\
\hline $\begin{array}{l}\text { UR \& } \\
\text { SO }\end{array}$ & $\begin{array}{c}1 \text { half-street }+3 \text { exchange } \\
\text { structures ( } 2 \text { ways: collect } \\
\text { and overflow) } \\
\end{array}$ & $\begin{array}{c}\text { University of A } \\
\text { Coruna (A Coruna, } \\
\text { Spain) } \\
\end{array}$ & Fraga et al. (2017) & & 6 & $\mathrm{~S}+\mathrm{U}$ & $5[\mathrm{~B}]$ & $\begin{array}{l}\text { Water depth in street and in } \\
\text { pipes + discharge in pipes }\end{array}$ & $\mathrm{SF}=1$ & (23) \\
\hline \multirow{7}{*}{ UR } & & & & III Flow through a & egular grid o & lerging obstacles & & & & \\
\hline & \multirow{6}{*}{$\begin{array}{l}\text { Non-uniform flow } \\
\text { in a patch of obstacles }\end{array}$} & \multirow{3}{*}{$\begin{array}{l}\text { UCL (Louvain la } \\
\text { Neuve, Belgium) }\end{array}$} & $\begin{array}{c}\text { Soares-Frazão } \\
\text { and Zech (2008) }\end{array}$ & \multirow{2}{*}{$\begin{array}{l}\text { aligned obstacle } \\
\text { grid (aligned with } \\
\text { flow axis and } \\
\text { rotated) }\end{array}$} & \multirow{3}{*}{15} & U (dam break) & $2[\mathrm{~B}]$ & $\begin{array}{c}\text { Water depth } \\
\text { Surface velocity fields }\end{array}$ & \multirow{3}{*}{$\begin{array}{l}\mathrm{S}_{\mathrm{w}}=0.1 \mathrm{~m} \\
\mathrm{SF} \sim 1 / 150\end{array}$} & (24) \\
\hline & & & $\begin{array}{l}\text { Velickovic et al. } \\
\text { (2017) }\end{array}$ & & & \multirow[b]{2}{*}{$\mathrm{S}$} & $20[\mathrm{~B}]$ & Water depth profiles & & (25) \\
\hline & & & $\begin{array}{l}\text { Lhomme et al. } \\
\qquad(2007)\end{array}$ & $\begin{array}{l}\text { Staggered obstacle } \\
\text { grid (aligned with } \\
\text { flow axis) }\end{array}$ & & & $1[\mathrm{D}]$ & $\begin{array}{c}\text { Water depths } \\
\text { Surface velocity fields }\end{array}$ & & (26) \\
\hline & & CESI (Milan, Italy) & Testa et al. (2007) & $\begin{array}{c}\text { aligned \& } \\
\text { staggered obstacles }\end{array}$ & 5 & U (dam break) & $12[\mathrm{~A}]$ & Water depths & $\mathrm{SF}=1 / 100$ & (27) \\
\hline & & $\begin{array}{l}\text { National Taiwan } \\
\text { University (Taiwan) }\end{array}$ & $\begin{array}{l}\text { Huang et al. } \\
\text { (2014) }\end{array}$ & $\begin{array}{l}\text { aligned obstacles } \\
\text { (aligned with flow } \\
\text { axis) }\end{array}$ & 8 & S & $7[\mathrm{D}]$ & Water depth profiles & Various $S_{w}$ & (28) \\
\hline & & KICT (South Korea) & Kim et al. (2015) & Aligned obstacles & 30 & U (dam break) & $2[\mathrm{D}]$ & Water depths & $\begin{array}{l}\mathrm{S}_{\mathrm{W}}=0.1 \mathrm{~m} \\
\mathrm{SF} \sim 1 / 150\end{array}$ & (29) \\
\hline
\end{tabular}




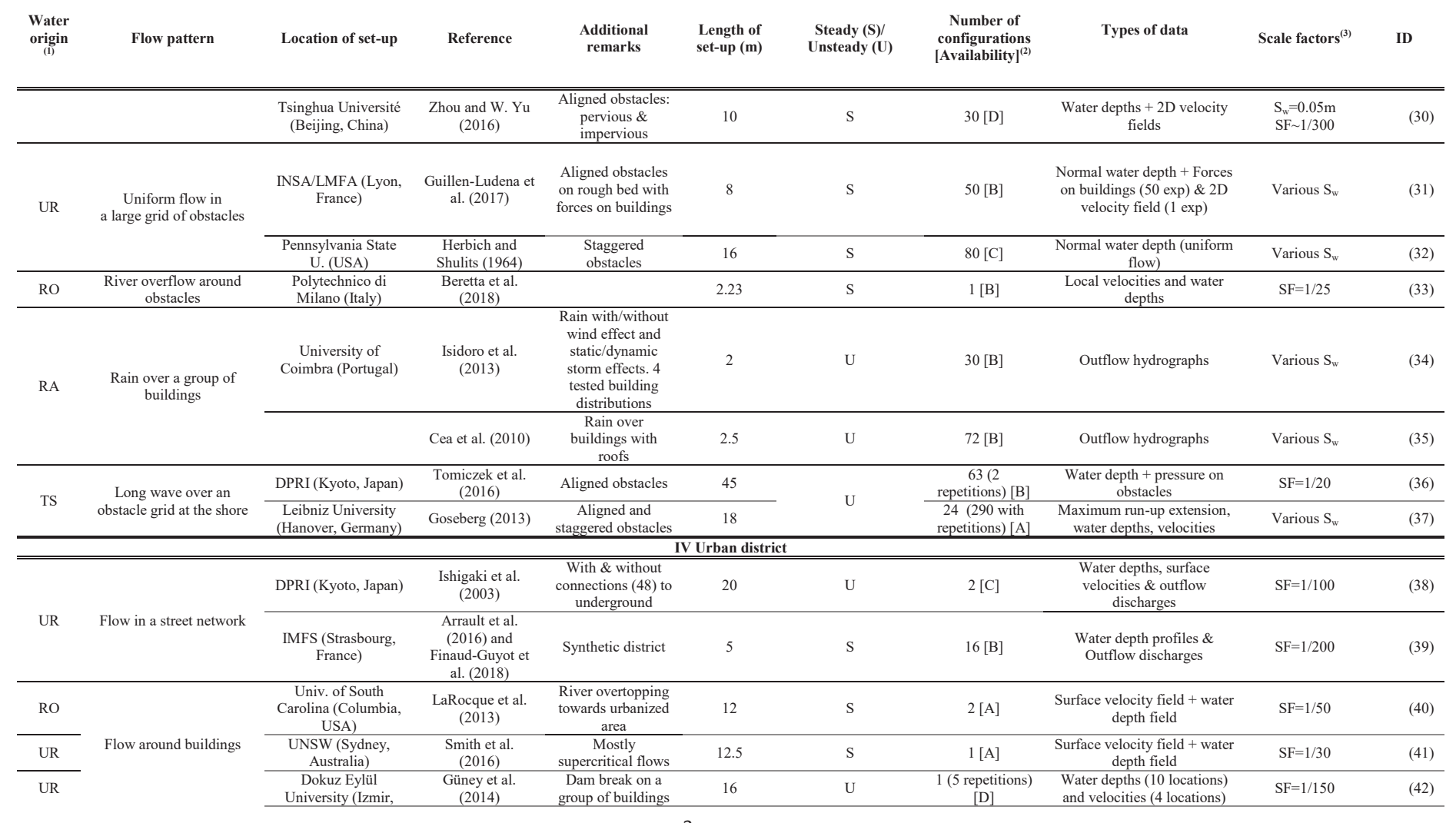




\begin{tabular}{|c|c|c|c|c|c|c|c|c|c|c|}
\hline $\begin{array}{l}\text { Water } \\
\text { origin } \\
\text { (1) }\end{array}$ & Flow pattern & Location of set-up & Reference & $\begin{array}{l}\text { Additional } \\
\text { remarks }\end{array}$ & $\begin{array}{l}\text { Length of } \\
\text { set-up (m) }\end{array}$ & $\begin{array}{l}\text { Steady (S)/ } \\
\text { Unsteady (U) }\end{array}$ & 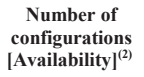 & Types of data & Scale factors ${ }^{(3)}$ & ID \\
\hline & & Turquey) & & & & & & & & \\
\hline RO & & $\begin{array}{c}\text { University of } \\
\text { Innsbruck (Austria) }\end{array}$ & $\begin{array}{l}\text { Sturm et al. } \\
\quad(2018)\end{array}$ & $\begin{array}{l}\text { Supercritical \& } \\
\text { flow within } \\
\text { buildings }\end{array}$ & 9 & $\begin{array}{c}\mathrm{U} \text { (Fixed discharge } \\
\text { in the river } \\
\text { upstream) }\end{array}$ & $\begin{array}{l}140 \\
{[D]}\end{array}$ & $\begin{array}{l}\text { Forces on buildings, water } \\
\text { depths, flow velocities }\end{array}$ & $\mathrm{SF}=1 / 30$ & (43) \\
\hline \multirow{2}{*}{ TS } & \multirow{2}{*}{$\begin{array}{l}\text { Long wave over a realistic } \\
\text { planning at the shore }\end{array}$} & $\begin{array}{l}\text { PARI (Yokosuda, } \\
\text { Japan) }\end{array}$ & Yasuda (2004) & $\begin{array}{l}\text { with openings } \\
\text { towards } \\
\text { underground }\end{array}$ & 34 & \multirow{2}{*}{$\mathrm{U}$} & $4[\mathrm{C}]$ & $\begin{array}{l}\text { Water depths + flood } \\
\quad \text { extension }\end{array}$ & $\mathrm{SF}=1 / 50$ & (44) \\
\hline & & $\begin{array}{c}\text { Oregon State } \\
\text { University } \\
\text { (Corvallis, USA) }\end{array}$ & Park et al. (2013) & & 40 & & $\begin{array}{c}1 \text { ( } 99 \\
\text { repetitions) [B] }\end{array}$ & Water depths and velocities & $\mathrm{SF}=1 / 50$ & (45) \\
\hline
\end{tabular}

(1) $\mathrm{UR}=$ Upstream runoff, $\mathrm{RO}=$ River overflow, $\mathrm{SO}=$ Sewer overflow, $\mathrm{TS}=\mathrm{T}$ sunami, $\mathrm{RA}=$ Rain over the domain

${ }^{(2)} \mathrm{A}=$ Available on the Internet or in the article, $\mathrm{B}=$ Available upon demand, $\mathrm{C}=$ Likely not available, $\mathrm{D}=$ No information about availability

${ }^{(3)} \mathrm{S}_{\mathrm{W}}=$ street width in model, $\mathrm{G}_{\mathrm{W}}=$ gully width in model, $\mathrm{SF}=$ horizontal scale factor reported by authors or computed using typical field values $\mathrm{S}_{\mathrm{w}}=15 \mathrm{~m}$ and $\mathrm{G}_{\mathrm{W}}=0.6 \mathrm{~m}$ in prototype

Note: In terms of discharge distribution in 3-branch subcritical and transcritical bifurcation flow configurations without obstacle (very simple cases), the recent works by Rivière et al. $(2011,2014)$ propose a review of available discharge distribution data. The reader can refer to these papers for a list of available data and corresponding references. 
Table 2: Urban flood processes and corresponding data availability for validation

\begin{tabular}{|c|c|c|c|}
\hline $\begin{array}{c}\text { Main } \\
\text { processes }\end{array}$ & Sub-processes & Id. from Table 1 & $\mathbf{S , C}$ \\
\hline \multirow{6}{*}{$\begin{array}{l}\text { Origin of } \\
\text { the water }\end{array}$} & Rain on urban domain & 34,35 & $\mathrm{~S}$ \\
\hline & River overtopping towards urban area & $33,40,43$ & $\mathrm{C}$ \\
\hline & Dam break upstream from city & $24,27,29,42$ & $\mathrm{C}$ \\
\hline & Tsunami (long) wave invading the city & $36,37,44,45$ & $\mathrm{C}$ \\
\hline & Wave submersion / storm surges & Not available & - \\
\hline & Sewage overflow & $15,19-23$ & $\mathrm{C}$ \\
\hline \multirow{12}{*}{$\begin{array}{l}\text { Flow in } \\
\text { streets }\end{array}$} & $\begin{array}{l}\text { Open-channel flows around a group of buildings: } \\
\text { - Steady sate }\end{array}$ & $25,26,28,30-33,40,41$ & $\mathrm{C}$ \\
\hline & $\begin{array}{l}\text { - Transient flow (bank overtopping, flood } \\
\text { wave, dike submersion wave...) }\end{array}$ & $24,27,29,34-37,42-45$ & $\mathrm{C}$ \\
\hline & - Subcritical flow regime & $25,26,28,30-33$ & $\mathrm{C}$ \\
\hline & - Supercritical flow regime & 41,43 & $\mathrm{~S}$ \\
\hline & - Wave front & $24,27,29,36,37,42,44,45$ & $\mathrm{C}$ \\
\hline & Open-channel flows in one street intersection & $1-14$ & $\mathrm{C}$ \\
\hline & Open-channel flows in a street network: & & \\
\hline & - Steady & 39 & $\mathrm{~S}$ \\
\hline & - Transient flow & 38 & $\mathrm{~S}$ \\
\hline & - Subcritical flow regime & 38,39 & $\mathrm{~S}$ \\
\hline & - Supercritical flow regime & Not available & - \\
\hline & Flow interaction with fixed furniture & 6 & $\mathrm{~S}$ \\
\hline \multirow{7}{*}{$\begin{array}{l}\text { Flow in } \\
\text { other } \\
\text { compart- } \\
\text { ments of } \\
\text { the urban } \\
\text { fabric }\end{array}$} & Sewer-street exchanges: & & \\
\hline & - 1 exchange structure & $15-20$ & $\mathrm{C}$ \\
\hline & $\begin{array}{l}\text { - } 1 \text { street \& } 1 \text { pipe with exchange } \\
\text { structures }\end{array}$ & $21-23$ & $\mathrm{~S}$ \\
\hline & $\begin{array}{l}\text { - Street \& pipe network with exchange } \\
\text { structures }\end{array}$ & Not available & - \\
\hline & $\begin{array}{l}\text { Flow within and through buildings / building } \\
\text { blocks }\end{array}$ & 30, 43 + Liu et al. (2018) & $\mathrm{S}$ \\
\hline & $\begin{array}{l}\text { Flow through open-areas: gardens / semi- } \\
\text { urbanized private parcel / above walls / through } \\
\text { vegetated or semi-pervious fences... }\end{array}$ & Not available & - \\
\hline & Flow in underground spaces & $38+$ Takayama et al. (2007) & $\mathrm{S}$ \\
\hline \multirow{10}{*}{$\begin{array}{l}\text { Associated } \\
\text { events }\end{array}$} & Cars transport : & & \\
\hline & - Stability of a single car & $\operatorname{Ref}^{(1)}$ & $\mathrm{C}$ \\
\hline & $\begin{array}{l}\text { - A group of cars in one street intersection } \\
\text { creating dams }\end{array}$ & Not available & - \\
\hline & $\begin{array}{l}\text { - Single car or a group of cars transported } \\
\text { in a street network }\end{array}$ & Not available & - \\
\hline & $\begin{array}{l}\text { Risk and evacuation of people : } \\
\text { • Human stability }\end{array}$ & $\operatorname{Ref}^{(2)}$ & $\mathrm{C}$ \\
\hline & $\begin{array}{l}\text { - Human evacuation (through doors, } \\
\text { corridor, staircase, from cars) }\end{array}$ & $\operatorname{Ref}^{(3)}$ & $\mathrm{S}$ \\
\hline & Forces on buildings & 31,43 & $\mathrm{~S}$ \\
\hline & Sediment transport & 43 & $\mathrm{~S}$ \\
\hline & $\begin{array}{l}\text { Rescue access and processes (via army, } \\
\text { ambulance, fire-men, etc...) }\end{array}$ & Not available & - \\
\hline & Pollution dispersion & Not available & - \\
\hline
\end{tabular}

\footnotetext{
${ }^{*} \mathrm{~S}=$ scare, $\mathrm{C}=$ comprehensive

${ }^{(1)}$ see recent extensive review by Martínez-Gomariz et al. (2018) and recent work by Martínez-Gomariz et al. (2017).

(2) see Abt et al. (1989), Russo, Gómez, and Macchione (2013), Xia et al. (2014), Martínez-Gomariz et al. (2016) and the review by Kvocka et al. (2016); older papers also exist.
} 
${ }^{\text {(3) }}$ see Ishigaki et al. (2008) and Baba et al. (2017) 
Table 3: Typology of numerical models applied to compute urban flood events

Type of model

Typical processes

Level of development ${ }^{(4)}$

Available

exp. data

(Yes, No)

\begin{tabular}{|c|c|c|c|}
\hline 3D RANS ${ }^{(1)}$ or LES ${ }^{(2)}$ & $\begin{array}{l}1 \text { street intersection } \\
\text { Flow around } 1 \text { building }\end{array}$ & $\mathrm{C}$ & $\mathrm{Y}$ \\
\hline $2 \mathrm{D} \mathrm{SWE}{ }^{(3)}$ & Street surface (local to large scale) & $\mathrm{C}$ & $\mathrm{Y}$ \\
\hline 2D SWE + porosity models & Urban district & $\mathrm{C} / \mathrm{R}$ & $\mathrm{Y}$ \\
\hline $\begin{array}{c}1 \mathrm{D}-2 \mathrm{D} \text { SWE } \\
(1 \mathrm{D}=\text { streets } / 2 \mathrm{D}=\text { crossroads })\end{array}$ & Urban district & $\mathrm{R}$ & $\mathrm{Y}$ \\
\hline $\begin{array}{c}1 \mathrm{D}-2 \mathrm{D} \text { SWE } \\
(1 \mathrm{D}=\text { sewer } / 2 \mathrm{D}=\text { streets })\end{array}$ & Coupled flow in streets and sewers & $\mathrm{R}$ & Y \\
\hline $\begin{array}{l}\text { 2D SWE or Boussinesq-type } \\
\text { equations }\end{array}$ & Overland Tsunami & $\mathrm{C}$ & Y \\
\hline $\begin{array}{c}\text { Hydrodynamics } \\
+ \text { morphodynamic model }\end{array}$ & $\begin{array}{l}\text { Building foundation scour, sediment } \\
\text { deposits around buildings... }\end{array}$ & $\mathrm{U}$ & $\mathrm{N}$ \\
\hline $\begin{aligned} & \text { Hydrodynamics } \\
&+ \text { empirical /analytical } \\
& \text { exchange formulae }\end{aligned}$ & $\begin{array}{l}\text { Flow exchange between streets and } \\
\text { built-up or open areas through } \\
\text { openings (gates, doors, windows...) }\end{array}$ & $\mathrm{U}$ & $\mathrm{N}$ \\
\hline $\begin{array}{c}\text { Hydrodynamics } \\
+ \text { advection-diffusion model }\end{array}$ & Pollutant transport & $\mathrm{U}$ & $\mathrm{N}$ \\
\hline $\begin{aligned} & \text { Hydrodynamics } \\
+ & \text { Lagrangian model }\end{aligned}$ & $\begin{array}{l}\text { Transport of urban furniture and } \\
\text { debris (cars, trees, etc...) }\end{array}$ & $\mathrm{U}$ & $\mathrm{N}$ \\
\hline $\begin{aligned} & \text { Hydrodynamics } \\
+ & \text { agent based model }\end{aligned}$ & Citizen evacuation, rescue access & $\mathrm{R}^{(5)}$ & $\mathrm{N}$ \\
\hline $\begin{array}{l}\text { Reynolds-averaged Navier-Sto } \\
\text { Large-Eddy simulations; } \\
\text { Shallow-water equations (see } \mathrm{R} \\
\mathrm{C}=\text { common practice, } \mathrm{R}=\text { rese } \\
\text { Mostly for tsunami cases, see } \mathrm{f}\end{array}$ & $\begin{array}{l}\text { uations; } \\
\text { 017) for details of the models and a } \\
\text { odels, } U=\text { unavailable in the conte } \\
\text { ance Wang et al. (2016). }\end{array}$ & & \\
\hline
\end{tabular}

